\title{
Determinants of Profitability of Bushmeat Marketing in Oluyole Local Government, Oyo State, Nigeria
}

\section{${ }^{* 1}$ LAYADE, KT; ${ }^{2}$ LAYADE, AA; ${ }^{1}$ OWOEYE, YT; ${ }^{1}$ ADENIKA, OA; ${ }^{1}$ OYEDIJI, OT}

\author{
${ }^{1}$ Onigambari Research Station, Forestry Research Institute of Nigeria \\ ${ }^{2}$ National Horticultural Research Institute, Ibadan, Oyo State, Nigeria \\ *Corresponding Author Email: toplay408@gmail.com
}

\begin{abstract}
The study was carried out to find out the determinants of profitability in bushmeat marketing in Oluyole Local Government, Oyo state, Nigeria. Primary data were obtained through the use of thirty structured questionnaire administered to bushmeat marketers using a random sampling technique. Data collected were analyzed using descriptive statistics, market efficiency and regression analysis. The results showed that all the respondents were female $(100 \%)$ and married $(84 \%)$. The mean age of the respondents was $48.0 \pm 7.0$ years, $83.3 \%$ had formal education with average year of experience of $24.0 \pm 8.0$ years in bushmeat marketing. Profitability analysis revealed that bushmeat marketing is profitable venture with an average market margins of $\$ 25,309.00$ and $\$ 6,433.33$ per week for fresh and smoked bushmeat respectively. The marketing efficiency was greater than unity (ME $>1)$. Regression analysis result indicated a significant relationship between year of education, marital status, membership of association and the marketing margin $(\mathrm{p}<0.01)$. The study thus recommends a policy that will regulate marketing of bushmeat to further enhance its efficiency in the study area.
\end{abstract}

\section{DOI: $\underline{\text { https://dx.doi.org/10.4314/jasem.v25i5.4 }}$}

Copyright: Copyright $\odot 2021$ Layade et al. This is an open access article distributed under the Creative Commons Attribution License (CCL), which permits unrestricted use, distribution, and reproduction in any medium, provided the original work is properly cited.

Dates: Received: 20 March 2021; Revised: 27 April 2021; Accepted: 07 May 2021

Keywords: Marketers, bushmeat, fresh, smoked, profitability

Next to timber, bush meat is one of the most valuable non-wood products obtained from tropical forest. (Wilkie and Carpenter, 1999). It is an important source of protein for human, and they contain less saturated fat and essential omega 3 fatty acid and rich in vitamins and some minerals (Oboye, 2017). National estimation of the value of the domestic trade in bush meat ranges from US\$42 to US\$205 million across countries in West and Central Africa (Davies, 2002). The supply of bush meat from wild sources can serve as the possible measure to bridge the gap between livestock production and human population growth which means that marketing of bush meat can play a vital role in meeting basic needs of hunters and other stakeholders found along the value chain. (Ayodele, et al, 1 999). Marketing has been defined as the management process responsible for identifying, anticipating and satisfying customer requirements profitably. (Chartered Institute of Marketing, 2015). Marketing efficiency is defined as the degree of market performance (Bagchi and Raha (2011) and an efficient market system is one that provides satisfactory and cheap services to consumers or one that maximize the ratio of input and output of marketing (Esiobu and Onubuogu, 2014). An efficient marketing system make sure that seasonal goods will be available all year round, with little variation in prices, which can be attributed to cost of marketing functions like storage, processing, transportation, etc. (Nwaru et al. 2011). Marketing of bush-meat provides a significant contribution to human livelihood, generates income for a large number of people including the hunters, traders and transporters both urban and rural areas (FAO, 2004). Hence, to be more profitable, bush meat marketing requires every action that increases sales income and as well decreasing the costs of marketing. Since profitability is the primary goal of all business prioritizing the adopted marketing strategies in order to improve profit becomes necessary. So measuring current and past profitability and projecting future profitability is very important. (Adedeji et.al, 2019). Therefore this paper evaluates the determinants factors of profitability of bushmeat marketing in Oluyole Local Government, Oyo State, Nigeria.

\section{MATERIALS AND METHODS}

Study Area: The study was carried out in Oluyole Local Government Area, Oyo state, Nigeria. The Local Government is located in South Eastern part of the State and lies at latitude $7^{\circ} 23^{\prime} 47^{\prime \prime} \mathrm{N}$ and longitude $3^{\circ} 56^{\prime} 0$ "E. The city covers an area of about 3,080 square kilometers with annual rainfall ranges from 
$100 \mathrm{~mm}$ to $1500 \mathrm{~mm}$ and average daily temperature of $24.1^{\circ} \mathrm{C}$ and $28^{\circ} \mathrm{C}$. The target population was bushmeat marketers

Sampling Technique and Data Collection: A random sampling technique was adopted to select the respondents for the study. Forty percent of the members in the list of membership provided by Ifelodun bushmeat marketers association were selected for the study. Primary data were collected through the use of structured questionnaire administered to the respondents complemented with oral interview. Information obtained from the respondents include: sex, age, marital status, years and level of education and marketing information (years of experience in bushmeat marketing, purchase and selling prices etc).

Data Analysis: Data were analyzed using descriptive statistics, market margin and marketing efficiency. Descriptive statistics were employed to describe socio-economic characteristics of the respondents.

Marketing margin and efficiency: Marketing margin and efficiency was calculated as follows:

$$
\begin{aligned}
& M M=A T R-A T M C \\
& M E=A T R / A T M C \ldots .
\end{aligned}
$$

Where, MM=Marketing Margin; $\mathrm{ME}=$ Marketing Efficiency; ATR=Average Total Revenue; ATMC $=$ Average Total Market Cost

Regression model specification

$Y=f\left(X_{1}, X_{2}, X_{3}, X_{4}, X_{5}, e\right)$

$Y=\beta_{0}+\beta_{1} X_{1}+\beta_{2} X_{2}+\beta_{3} X_{3}+\beta_{4} X_{4}+\beta_{5} X_{5}+e_{\ldots \ldots . . .4}$

Where; $\mathrm{Y}=$ marketing margin (dependent variable; $\mathrm{X}_{1}-\mathrm{X}_{5}=$ determinants of marketing margin

Where: $\mathrm{X}_{1}=$ Age; $\mathrm{X}_{2}=$ Marital status; $\mathrm{X}_{3}=$ Year of education; $\mathrm{X}_{4}=$ Marketing experience (Years); $\mathrm{X}_{5}=$ Membership of association; $\mathrm{e}=$ Error term; $\beta_{0}-\beta_{5}=$ Coefficients of Independent variables

\section{RESULTS AND DISCUSSION}

Socio-economic characteristics of respondents: Table 1 presents the socio-economic profile of bushmeat marketers in the study area. The result indicated that all the respondents were female $(100 \%)$ and married (84\%), indicating that women play a dominant role in bushmeat trading. This is in line with the findings of Soaga (2014) and
Babalola and Oladipupo, 2018 who reported that majority of bushmeat marketers were females. The average age of the respondents was $48.0 \pm 7.0$ years. This indicates that the respondents were mostly young adults and can withstand the stress in the business. The respondents $(83.3 \%)$ had formal education with average year of experience of 24.0 \pm 8.0 years in the business. This is an indication that the respondents were literate and have experience in the business.

Table 1: Socio-economic characteristics of respondents in the

\begin{tabular}{ll}
\multicolumn{2}{c}{ study area } \\
\hline Variable & Value \\
\hline \% female & 100.00 \\
Age (years) & $48.00 \pm 7.00$ \\
$\%$ Married & 84.00 \\
$\%$ Formal education & 83.30 \\
Household size & $6.00 \pm 3.00$ \\
Years of experience in bushmeat & $24.00 \pm 8.00$ \\
\hline \multicolumn{2}{c}{ Source: Field survey, 2020. }
\end{tabular}

Quantity and selling price of some of the bushmeat sold weekly: The quantities and average selling prices of animals commonly sold in the study area were presented in table 2. Out of nine major bushmeat identified in the market, giant rats, rabbit and grasscutter are commonly sold in the study area which is in line with the findings of Halidu, 2009.

Marketing efficiency of fresh and smoked bushmeat: In table 3, the marketing efficiencies for fresh and smoke bushmeat were greater than one implying that fresh and smoked bushmeat marketing are efficient in the study area. Bushmeat marketers were able to realize sufficient amounts of capital invested as returns, implying that bushmeat marketing is profitable in the study area. However, more profit was realized from the sale of fresh bushmeat compared to smoked meat (Table 3 ). In addition, response from the oral interview revealed that marketers preferred selling their bushmeat fresh. They reported that fresh bushmeat commands better price. Most times they process smoked meat if they are not able to sell the fresh meat.

Regression analysis of the determinants of profitability in bushmeat marketing: The result of a linear regression showed that coefficient of determination $\left(\mathrm{R}^{2}\right)$ was 0.578 which implied the independent variables accounted for $57.8 \%$ of total variation in dependent variable. F-value was 6.568; which implied that the model was significant at $1 \%$. Regression results revealed that year of education was positively significant to marketing margin. Education tends to affect reasoning; thus educated persons can easily understand and adopt innovation in the business (Ibekwe et al, 2012). Membership of association was 
also significant to marketing margin, this may be due to fact that members of bushmeat trade association derive some assistance that enhance their profits. The age of the respondents was significantly positive to market margin. Marital status was negatively significant to marketing margin at $1 \%$.

Table 2: Quantity and selling price of some of the bushmeat sold weekly

\begin{tabular}{|c|c|c|c|c|c|c|}
\hline \multirow[b]{2}{*}{$\begin{array}{l}\text { Wild animal } \\
\text { species }\end{array}$} & \multirow[b]{2}{*}{$\begin{array}{l}\text { Scientific } \\
\text { name }\end{array}$} & \multirow[b]{2}{*}{ Local name } & \multicolumn{2}{|c|}{ Fresh } & \multicolumn{2}{|c|}{ Smoked } \\
\hline & & & $\begin{array}{l}\text { Average } \\
\text { quantity } \\
\text { sold/week }\end{array}$ & $\begin{array}{l}\text { Average } \\
\text { Selling } \\
\text { Price/unit (\$) }\end{array}$ & $\begin{array}{l}\text { Average } \\
\text { quantity } \\
\text { sold/week }\end{array}$ & $\begin{array}{l}\text { Average } \\
\text { Selling } \\
\text { Price/unit (\#) }\end{array}$ \\
\hline Grasscutter & $\begin{array}{l}\text { Thryonomys } \\
\text { swinderianus }\end{array}$ & Оуа/Ешији & 8 & $6,792.68$ & 5 & $7,355.56$ \\
\hline Antelope & $\begin{array}{l}\text { Hippotragus } \\
\text { equines }\end{array}$ & Esuro & 1 & $24,024.39$ & 1 & $17,333.33$ \\
\hline Giant rat & $\begin{array}{l}\text { Crycetomys } \\
\text { gambianus }\end{array}$ & Okete & 11 & 995.12 & 7 & $1,319.44$ \\
\hline $\begin{array}{l}\text { Common gray } \\
\text { duiker }\end{array}$ & $\begin{array}{l}\text { Cephalophus } \\
\text { spp. }\end{array}$ & Etu & 1 & $6,750.00$ & 1 & $7,105.56$ \\
\hline Snake & $\begin{array}{l}\text { Dendroaspis } \\
\text { polylepis }\end{array}$ & Ejo & 3 & $2,152.78$ & 2 & $2,359.00$ \\
\hline Pangolin & Manis spp. & Aika & 3 & $7,000.00$ & 1 & $8,000.00$ \\
\hline Squirrel & $\begin{array}{l}\text { Protoxeryx } \\
\text { spp. }\end{array}$ & Okęrę & 4 & $1,341.67$ & 4 & $1,643.48$ \\
\hline Rabbit & $\begin{array}{l}\text { Orytolagus } \\
\text { cuniculus }\end{array}$ & Ehoro & 10 & $2,151.78$ & 4 & $2,395.65$ \\
\hline Bushbuck & $\begin{array}{l}\text { Tragelaphus } \\
\text { scriptus }\end{array}$ & Igala & 1 & 18,000 & & $20,333.33$ \\
\hline
\end{tabular}

Table 3: Marketing efficiency of fresh and smoked bushmeat

\begin{tabular}{|c|c|c|}
\hline & Fresh ( $¥)$ & Smoked ( $¥)$ \\
\hline Average Total Marketing Cost per week & $110,047.67$ & $44,490.00$ \\
\hline Average Total Revenue per week & $135,356.67$ & $50,923.33$ \\
\hline Market margin & $25,309.00$ & $6,433.33$ \\
\hline Marketing efficiency & 1.23 & 1.15 \\
\hline
\end{tabular}

Table 4: Regression results of the determinants of marketing margin

\begin{tabular}{llll}
\hline & $\begin{array}{l}\text { Independent } \\
\text { variables }\end{array}$ & B & t-value \\
\hline Age & Constant & 162648.235 & 2.882 \\
Marital status & $\mathrm{X}_{1}$ & 1615.597 & $1.865^{*}$ \\
Year of education & $\mathrm{X}_{2}$ & -78352.478 & $-4.072^{* * *}$ \\
Marketing experience & $\mathrm{X}_{3}$ & 3591.899 & $3.424^{* * *}$ \\
Membership of association & $\mathrm{X}_{4}$ & 783.992 & 1.231 \\
$\mathrm{X}_{5}$ & 61708.182 & $3.316^{* * *}$ \\
\hline
\end{tabular}

***Significant at $1 \%, *$ Significant at $10 \%$ Dependent variable: Marketing margin, $R^{2}=0.578, F$-value $=6.568$.

Conclusion: Bushmeat marketing was profitable and dominated by women in the area. Greater profit was realized from the sale of fresh bushmeat compared to smoked carcass. Profitability indicators showed that bushmeat marketing is profitable.

However, there should be public enlightenment on the need to domesticate wild animal species to avoid over exploitation from the wild. Domestication and multiplication of fast growing species should be encouraged in the study area for consumptive utilization and sustainable management of animal in the wild.

Also, there should be a policy that will regulate marketing of bushmeat to further enhance its efficiency in the study area.

\section{REFERENCES}

Adedeji, T; Osundare, F; Ajiboye, A (2019). Profitability and marketing efficiency of smoked fish: an empirical evidence from Ondo state, Nigeria. J. Agric. Ext. Rur. Dev. Stud. 6(3): 2633 .

Ayodele, IA; Ebin, CO; Alarape, AA (1999). Essentials of wildlife management. Jachin Publisher.

Babalola, FD; Oladipupo, AD (2018). Evaluation of factors associated with bushmeat marketing in Igbomina District of Kwara State, Nigeria. J. Forest. Res. Manage. 15(1):3-50. 
Bagchi, M; Raha, SK (2011). Post-harvest loss of flower and its impacts on flower marketing in Bangladesh. J. Econ. Affai. 2(56):205-211

Davies, G (2002). Bushmeat and International Development. Conserv. Biol. 16(3):587-589.

Esiobu, NS; Onubuogu, GC (2014). Socio-economic Analysis of frozen fish marketing in Owerri municipal council area, Imo State, Nigeria: An econometric model approach. Scholar. J. Agric. Sci. 4(8):449-459.

FAO (2004). The bushmeat crisis in Africa : conciliation food security and biodiversity conservation in the content $23^{\text {rd }}$ regional conference for Africa held in South Africa 1-5 March,2004.

Halidu, KS (2019). Assessment of bushmeat sale and its implication on wildlife conservation in Old Oyo National Park, Nigeria. Worl. New. Natur. Sci. 23(2019):266-275.

Ibekwe, UC; Chikezie, C; Obasi, PC; Eze, CC; HenriUkoha, A (2012). Profitability of garri processing in Owerri North Local Government Area of Imo State. ARPN J. Sci. Tech. 2(4):340-343.
Nwaru, JC; Nwosu, AC; Agummuo, VC (2011). Socio-economic determinants of profit in wholesale and retail banana marketing in Umuahia agricultural zone of Abia State, Nigeria. J. sust. Dev. Afr., 13(1):200-210.

Oboye, O (2017). The good and ugly side of eating bushmeat. Punch newspaper published 27/10/2017.

Soaga, JA; Shotuyo, ALA; Oduntan, OO; Fatoki, JG (2014). Economic analysis of bushmeat trade in Abeokuta, Ogun State. J. Agric. Sci. Environ. 14:97-108.

Wilkie, DS; Carpenter, JF (1999). Bushmeat hunting in the Congo Basin: an assessment of impacts and options for mitigation. Biodiver. Conserv. 8(7):927-955. 